\title{
It Was Found That Amino Sugar Nitrogen Was a New Source of Energy for Plant
}

\author{
Shushan $\mathrm{Li}^{1,2}$, Lian Liu ${ }^{3}$, Huimin Jiang ${ }^{1,2}$, Jianfeng Zhang ${ }^{1,2}$, Pan Pan ${ }^{3}$, Shuiqin Zhang ${ }^{1,2}$, Junmei Guo ${ }^{1,2}$, \\ Jinming Zhang ${ }^{4}$ \& Juncheng Yang ${ }^{1,2}$ \\ ${ }^{1}$ Institute of Agricultural Resources and Regional Planning, Chinese Academy of Agricultural Sciences, P. R. \\ China \\ ${ }^{2}$ National Engineering Laboratory for Improving Quality of Arable Land, Beijing, P. R. China \\ ${ }^{3}$ College of Resource and Environment, Sichuan Agricultural University, Chengdu, P. R. China \\ ${ }^{4}$ Department of Nuclear Medicine; the General Hospital of PLA, Beijing, P. R. China \\ Correspondence: Juncheng Yang, Institute of Agricultural Resources and Regional Planning, Chinese Academy of \\ Agricultural Sciences, P. R. China; National Engineering Laboratory for Improving Quality of Arable Land, \\ Beijing, P. R. China. Tel: 86-10-8210-6203. E-mail:yangjuncheng@caas.cn
}

Received: November 11, 2013 Accepted: December 17, 2013 Online Published: January 15, 2014

doi:10.5539/jas.v6n2p45 URL: http://dx.doi.org/10.5539/jas.v6n2p45

\begin{abstract}
Amino sugar nitrogen (ASN) is one of the most important nitrogen sources for plants. Whether ASN such as glucosamine can be absorbed directly by plants has remained unclear, because the technology for investigating its mechanism of absorption has been lacking. Using Positron Emission Tomography (PET) with ${ }^{18} \mathrm{~F}$-fluorodeoxyglucose $\left({ }^{18} \mathrm{~F}-\mathrm{FDG}\right)$, we observed that ASN was absorbed directly by tomatoes and rice and this absorption was significantly influenced by the carbon to nitrogen ratio $(\mathrm{C} / \mathrm{N})$ and the $\mathrm{pH}$ value of the growth substrate solution of tomatoes and rice. Absorption and transportation of ASN was measured at $\mathrm{C} / \mathrm{N}$ ratios of 10 or 25 at $\mathrm{pH} 7.0$ or 8.0 in tomato and at $\mathrm{pH} 5.5$ or 6.5 in rice. A C/N ratio of 10 resulted in higher ASN absorption and transportation than a $\mathrm{C} / \mathrm{N}$ ratio of 25 in both tomatoes and rice. At $\mathrm{C} / \mathrm{N}$ ratio of 10 , tomatoes absorbed more ASN at $\mathrm{pH} 8.0$ than at $\mathrm{pH}$ 7.0. In rice, absorption was more at $\mathrm{pH} 5.5$ than 6.5. In a word, a lower $\mathrm{C} / \mathrm{N}$ ratio yielded a higher ASN absorption and transportation for both tomatoes and rice. Tomatoes showed a slight preference for alkaline conditions, whereas rice preferred acidic conditions.
\end{abstract}

Keywords: amino sugar nitrogen, positron emission tomography, $\mathrm{C} / \mathrm{N}$, tomato, rice

\section{Introduction}

In 1965, Bremner popularized the study of organic nitrogen by showing, using acid digestion, that the organic nitrogen that forms in soil can be classified into amino acid nitrogen, amino sugar nitrogen (ASN), hydrolysable ammonium nitrogen, hydrolysable unidentified nitrogen and non-hydrolysable organic nitrogen (Bremner, 1965). Some researchers have demonstrated that plants can absorb not only mineralized nitrogen but also organic nitrogen such as no acid nitrogen (Schobert \& Komor, 1987; Schiller et al., 1998), for instance glycine, leucine and alanine (Zhang \& Sun, 1984; Falkengren et al., 2000; Persson \& Näsholm, 2003; Reeve et al., 2008). However, whether ASN, a refractory organic compound, can be directly used by plants remains unknown.

ASN comprises $5-10 \%$ of the total nitrogen in soil, it provides energy for plant growth and improves soil structure (Stevenson, 1982). It mainly exists in the chitinous substance of fungus and insect, 11 kinds of ASN have been detected by now. The ASN base in soil is glucosamine, which makes up approximately $59-63 \%$ of the total ASN, depending on the soil type (Table 1) (Bremner, 1967; Y. M. Liu \& X. H. Liu, 2010). The dynamic process of ASN absorption and transportation into plants is difficult to observe using conventional technology. 
Table 1. ASN distribution in three different soils

\begin{tabular}{|c|c|c|c|c|c|c|c|c|}
\hline & \multicolumn{2}{|c|}{ Glucosamine } & \multicolumn{2}{|c|}{ Galactosamine } & \multicolumn{2}{|c|}{ Epichitosamine } & \multicolumn{2}{|c|}{ Muramic acid } \\
\hline & $\left(\mathrm{mg} \cdot \mathrm{kg}^{-1}\right)$ & $(\%)$ & $\left(\mathrm{mg} \cdot \mathrm{kg}^{-1}\right)$ & $(\%)$ & $\left(\mathrm{mg} \cdot \mathrm{kg}^{-1}\right)$ & $(\%)$ & $\left(\mathrm{mg} \cdot \mathrm{kg}^{-1}\right)$ & $(\%)$ \\
\hline Black soil & 617.5 & 56.32 & 316.0 & 28.82 & 29.3 & 2.67 & 77.0 & 7.02 \\
\hline Brown soil & 644.3 & 63.22 & 269.7 & 26.46 & 28.2 & 2.77 & 70.4 & 6.91 \\
\hline Red soil & 463.8 & 59.23 & 141.5 & 18.07 & 20.1 & 2.57 & 78.5 & 10.02 \\
\hline
\end{tabular}

PET is a non-invasive imaging technology that is used to observe and probe biological processes in vivo in medicine (Lee et al., 2011). There is a structural similarity between FDG and glucosamine (structure shown in Figure 1) (Yang et al., 2004). At position 2 of the sugar, FDG and glucosamine have the fluorine and amino group, respectively. Similar to FDG, the cellular uptake of glucosamine is by a glucose transporter process (Yang et al., 2003). For example, PET with ${ }^{18} \mathrm{~F}-\mathrm{FDG}$ as a substitute for glucose or glucosamine has been used for clinical diagnosis by oncologists (Weissleder, 2006). It was developed in the 1990s to study the transfer activities within living plants, using positron-emitting isotopes. With this technology, dynamic real-time imaging of the isotope in plants can be carried out. Studies using PET technology and the positron-emitting isotope markers ${ }^{13} \mathrm{NH}_{4}^{+},{ }^{13} \mathrm{NO}_{3}^{-}, \mathrm{H}_{2}{ }^{18} \mathrm{~F}$ and ${ }^{11} \mathrm{CO}_{2}$ have been described (Ohtake et al., 2001; Nakanishi et al., 2001; Ryuichi et al., 2008). In 2008, Hattori et al. (2008) e first to demonstrate that a planar positron imaging system (PPIS) could also be used in plants non-invasively to detect the distribution of photosynthetic products substituted with ${ }^{18}$ F-FDG. In 2012, Ferrieri et al. (2012) demonstrated that ${ }^{18}$ F-FDG was a good metabolite for PPIS studies to assess the stress resistance of plants under various conditions. In the current study, ${ }^{18}$ F-FDG was used as a radioactive tracer to explore the uptake of ASN by plants using PET.

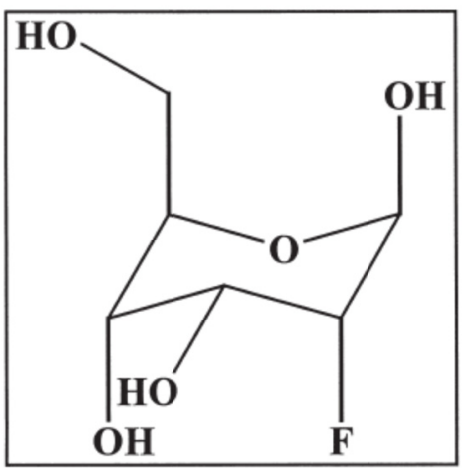

A

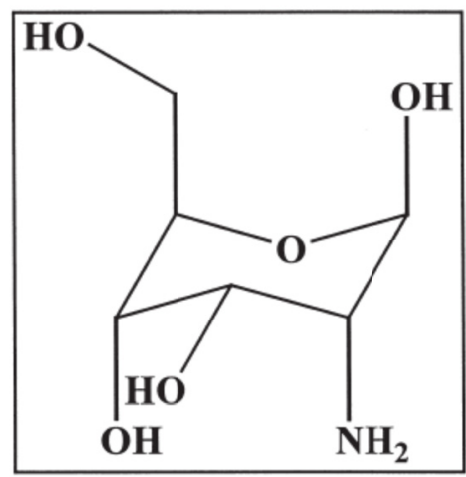

B

Figure 1. Chemical structures of ${ }^{18} \mathrm{~F}-\mathrm{FDG}(\mathrm{A})$ and glucosamine (B). ${ }^{18} \mathrm{~F}-\mathrm{FDG}$ is molecular formula is $\mathrm{C}_{6} \mathrm{H}_{11}{ }^{18} \mathrm{FO}_{5}$, and its molecular weight is 182 . The half-life of ${ }^{18} \mathrm{~F}-\mathrm{FDG}$ is $109.77 \mathrm{~min}$

\section{Materials and Methods}

2.1 The Synthesis of $2-{ }^{18} F-\beta$-D-deoxyglucose $\left({ }^{18} F-F D G\right)$

Anhydrous acetonitrile, Amino polyether $\mathrm{K}_{2 \cdot 2 \cdot 2} / \mathrm{K}_{2} \mathrm{CO}_{3}$ : USA Aldrich company; Sep-Pak $\mathrm{C} 18 / \mathrm{Al}_{2} \mathrm{O}_{3}$ column: USA Waters company; IC-H column: USA Alltech company; USP alcohol: USA Milliper company; $\mathrm{NaOH}, \mathrm{HCl}$ : Beijing Chemical Works.

HM-20S accelerator: JAP Sumitomo; ${ }^{18}$ F-FDG automatic synthesis module: Pat (Beijing) technology co., LTD.

${ }^{18}$ F-FDG was produced with a domestic ${ }^{18}$ F-FDG automatic synthesis module. First, after capture by QMA, the ${ }^{18} \mathrm{~F}$-products produced by the Sumitomo HM-20S accelerator were placed into a reaction tube after the $\mathrm{K}_{2.2 .2} / \mathrm{K}_{2} \mathrm{CO}_{3}$ acetonitrile solution was eluted. The azeotropic water was evaporated and then dried again after the addition of $2 \mathrm{ml}$ of acetonitrile. One milliliter of anhydrous acetonitrile solution containing $20 \mathrm{mg}$ of 3-fluorine mannose was then placed into reaction tubes and heated for $5 \mathrm{~min}$ at $83{ }^{\circ} \mathrm{C}$ after which the acetonitrile was removed and $14 \mathrm{ml}$ of water was added. The mixture was placed into a Sep-Pak C18 chromatography column, where the intermediate persisted in the column, which was washed twice with $10 \mathrm{ml}$ of water. Then, $1 \mathrm{ml}$ of $2 \mathrm{M}$ 
$\mathrm{NaOH}$ was added to the column, and the sample was hydrolyzed for 2 min at room temperature. Next, the hydrolysis reaction mixture was purified using an IC-H column, a Sep-Pak C18 column (which was activated with $5 \mathrm{ml}$ of alcohol before compounding), and an $\mathrm{Al}_{2} \mathrm{O}_{3}$ column. The final product was obtained after the column was washed with $10 \mathrm{ml}$ of water, and the product was then passed through a sterile membrane.

\subsection{Plant Materials and Growth Conditions}

Tomatoes (dicotyledons) and rice (monocotyledons) were selected as the crops. The tomato strain ZHONGZA NO.9 was supplied by the Institute of Vegetables and Flowers Chinese Academy of Agricultural Sciences, and the rice strain JIJING NO.88 was supplied by the Institute of Crop Science Chinese Academy of Agricultural Sciences. The seeds were sterilized with $10 \% \mathrm{H}_{2} \mathrm{O}_{2}$, washed with distilled water and germinated at room temperature on paper towels soaked with distilled water. After germination, the plantlets were transferred to a nursery site with vermiculite. After 5 days, the plants were transferred to substrate solution in a greenhouse under natural light. The substrate solution for tomato plants was $3.75 \mathrm{mM} \mathrm{Ca}\left(\mathrm{NO}_{3}\right)_{2} \cdot 4 \mathrm{H}_{2} \mathrm{O}, 1 \mathrm{mM} \mathrm{MgSO} \mathrm{maH}_{4} \cdot 7 \mathrm{H}_{2} \mathrm{O}, 1.5$ $\mathrm{mM} \mathrm{KH}_{2} \mathrm{PO}_{4}, 0.25 \mathrm{mM}\left(\mathrm{NH}_{4}\right)_{2} \mathrm{SO}_{4}, 1.25 \mathrm{mM} \mathrm{K}_{2} \mathrm{SO}_{4}, 3 \mathrm{mM} \mathrm{KNO}_{3}, 46 \mu \mathrm{M} \mathrm{H}_{3} \mathrm{BO}_{3}, 12.6 \mu \mathrm{M} \mathrm{MnSO}{ }_{4} \cdot \mathrm{H}_{2} \mathrm{O}, 0.77$ $\mu \mathrm{M} \mathrm{ZnSO} \cdot \cdot 7 \mathrm{H}_{2} \mathrm{O}, 0.32 \mu \mathrm{M} \mathrm{CuSO}_{4} \cdot 5 \mathrm{H}_{2} \mathrm{O}, 0.02 \mu \mathrm{M}\left(\mathrm{NH}_{4}\right)_{6} \mathrm{Mo}_{7} \mathrm{O}_{24} \cdot 4 \mathrm{H}_{2} \mathrm{O}$ and $0.05 \mu \mathrm{M}$ Fe-EDTA. The substrate solution for rice plants was $1 \mathrm{mM}\left(\mathrm{NH}_{4}\right)_{2} \mathrm{SO}_{4}, 0.3 \mathrm{mM} \mathrm{NaH}_{2} \mathrm{PO}_{4}, 0.7 \mathrm{mM} \mathrm{K}_{2} \mathrm{SO}_{4}, 2.0 \mathrm{mM} \mathrm{CaCl}_{2}, 0.5 \mathrm{mM}$ $\mathrm{MgSO}_{4}, 10 \mu \mathrm{M} \mathrm{H}_{3} \mathrm{BO}_{3}, 0.5 \mu \mathrm{M} \mathrm{MnSO}_{4}, 0.2 \mu \mathrm{M} \mathrm{CuSO}_{4}, 0.5 \mu \mathrm{M} \mathrm{ZnSO}_{4}, 0.01 \mu \mathrm{M}\left(\mathrm{NH}_{4}\right)_{6} \mathrm{Mo}_{7} \mathrm{O}_{24}$ and $0.1 \mathrm{mM}$ Fe-EDTA (Kiyomiya et al., 2001). For the different treatments, pH was adjusted using $0.1 \mathrm{M} \mathrm{HCl}$ and $\mathrm{NaOH}$ and the $\mathrm{C} / \mathrm{N}$ ratio was adjusted using glucose.

\subsection{Accumulation of Root Radioactivity}

Tomato and rice seedlings were placed in Petri dishes containing normal substrate solution (without ${ }^{18} \mathrm{~F}-\mathrm{FDG}$ ), and only the root could access the substrate solution. Next, $0.5 \mathrm{mCi}{ }^{18} \mathrm{~F}-\mathrm{FDG}$ was injected into the substrate solution, and 3 seedlings were removed from each dish at $0 \mathrm{~min}, 1 \mathrm{~min}, 5 \mathrm{~min}, 10 \mathrm{~min}, 20 \mathrm{~min}$, and $30 \mathrm{~min}$, flushed with deionized water and dried. The root was cut for radioactivity measurements with a well-type detector. The data were corrected using $109.77 \mathrm{~min}$ as the ${ }^{18} \mathrm{~F}$ half-life and according to the same count time.

\subsection{PET Imaging}

We injected $2.425 \mathrm{mCi}^{18} \mathrm{~F}$-FDG into every treated substrate solution. Five hours after injection, the plants were washed with deionized water and fixed on the Explore Vista Micro PET System for imaging. The data were automatically corrected using $109.77 \mathrm{~min}$ as the ${ }^{18} \mathrm{~F}$ half-life. We used image analysis software (VISTA-CT Visualization \& Analysis) to quantify the signal intensity in specific regions of interest. Subsequently, we separated the seedlings into their respective roots, stems and leaves to assess the radioactivity using the well-type detector. The data were corrected using $109.77 \mathrm{~min}$ as the ${ }^{18} \mathrm{~F}$ half-life and the same count time. Lastly, we quantified the radioactive contributions from the root, stem and leaf equaled the total plant radioactivity.

\section{Results}

\subsection{ASN Absorption in Roots}

To identify whether ASN is directly absorbed by plants, the specific activity of the roots of tomatoes and rice that had been dipped in ${ }^{18}$ F-FDG substrate solution was assayed. The specific activity of tomato roots showed an approximately linear increase with time from application of the tracer, within the first $30 \mathrm{~min}$ (Figure 2A). Maximal specific activity was not investigated. Specific activity also increased in rice roots, albeit at a different rate, with a slow increase in activity from $0 \mathrm{~min}$ to $20 \mathrm{~min}$ followed by a rapid increase from $20 \mathrm{~min}$ to $30 \mathrm{~min}$ (Figure 2B). It has been previously established that the passive absorption rate decreases as the osmotic pressure decreases. However, a reduction in the absorption rate was not observed in the current study; rather, an increased absorption rate from $20 \mathrm{~min}$ to $30 \mathrm{~min}$ in rice was observed, which suggests that rice absorbs ASN via an initiative-absorption-process. This discovery demonstrates that ASN is a nutritional source of plant organic nitrogen. Moreover, the rice roots displayed a greater amount of radioactivity than the tomato roots throughout the process, which is likely because rice, a monocotyledon, possesses more fibrils, and its roots therefore display a larger contact area with the substrate solution. 


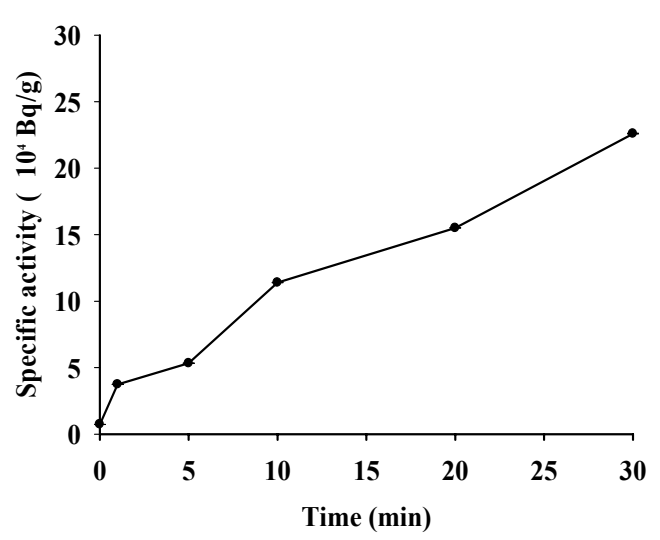

A

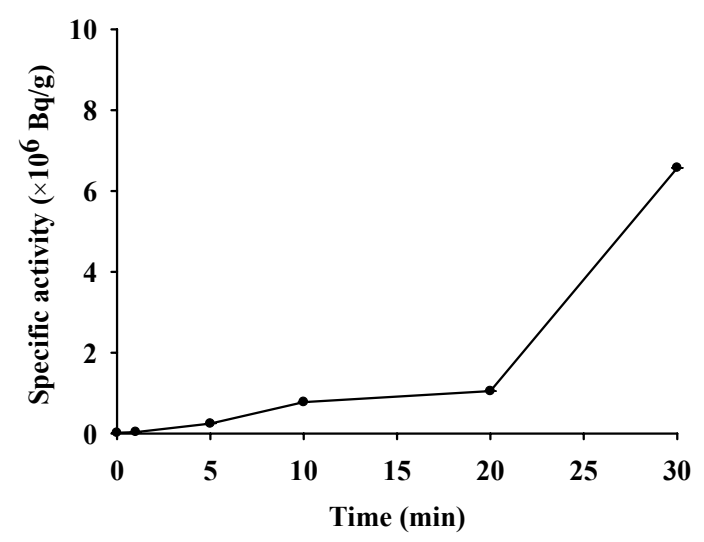

$\mathrm{B}$

Figure 2. Time course of accumulation of ${ }^{18} \mathrm{~F}-\mathrm{FDG}$ in the roots of tomatoes (A) and rice (B). Each plant experiment was repeated at least three times to confirm the reproducibility of the results. Error bars are the SD

\subsection{PET Imaging}

Absorption and transportation of ASN are influenced by the $\mathrm{pH}$ and $\mathrm{C} / \mathrm{N}$ ratio of plant growing environment. To assess the effects of $\mathrm{pH}$ and $\mathrm{C} / \mathrm{N}$ ratio on ASN absorption and transportation in tomatoes and rice, roots were dipped in ${ }^{18} \mathrm{~F}$-FDG substrate solution. A total of 8 distinct treatments at different $\mathrm{C} / \mathrm{N}$ ratio and $\mathrm{pH}$ values were tested. A C/N ratio of 10 or 25 was tested for each plant at either $\mathrm{pH} 7.0$ or 8.0 in tomato or $\mathrm{pH} 5.5$ or 6.5 in rice (Table 2) according to $\mathrm{pH}$ and $\mathrm{C} / \mathrm{N}$ of soil. ${ }^{18} \mathrm{~F}$ radioactivity images (Figure 3 ) showed that ${ }^{18} \mathrm{~F}$-FDG entered both tomato and rice plants. In tomato at either $\mathrm{pH} 7.0$ or 8.0 , the stem image at a $\mathrm{C} / \mathrm{N}$ ratio of 10 was clearer (the signal intensity was greater) than at a $\mathrm{C} / \mathrm{N}$ ratio of 25 , and the translocation was higher. At either $\mathrm{C} / \mathrm{N}$ ratio, the stem image at $\mathrm{pH} 8.0$ was clearer than at $\mathrm{pH} 7.0$, and the translocation was higher (the ${ }^{18} \mathrm{~F}-\mathrm{FDG}$ signal had travelled higher in the plant) (Figure 3A). These results demonstrated that, of the treatments tested, a $\mathrm{pH}$ of 8.0 and a $\mathrm{C} / \mathrm{N}$ ratio of 10 promoted the greatest ASN absorption and transportation in tomatoes. In rice, the images were clearer and the translocation was higher at a $\mathrm{C} / \mathrm{N}$ ratio of 10 for both $\mathrm{pH}$ conditions. The stem images were clearer, and the translocation was higher at $\mathrm{pH} 5.5$ than at $\mathrm{pH} 6.5$ for both $\mathrm{C} / \mathrm{N}$ ratios (Figure 3B). Therefore, a $\mathrm{pH}$ of 5.5 and a $\mathrm{C} / \mathrm{N}$ ratio of 10 yielded the strongest ASN absorption and transportation in rice. The discrimination center (DC) is the note of rice root and stem, it was observed in rice, where there was an accumulation of ${ }^{18} \mathrm{~F}$-FDG. This was consistent with previous studies that demonstrated that the DC could accumulate and sort nutrients (Hattori et al., 2008; A. Sigel \& H. Sigel, 1998; Nakanishi et al., 1999; Kiyomiya et al., 2001). The tomato and rice gray values (the specific activity detected in tomato and rice obtained by PET system) indicated the radioactivity, which also supported the results that a $\mathrm{pH}$ of 8.0 and a $\mathrm{C} / \mathrm{N}$ ratio of 10 promoted the strongest ASN absorption and transportation in tomatoes (Table 3).

Table 2. Tomato and rice treatments

\begin{tabular}{llll}
\hline Plants & Treatment & $\mathrm{pH}$ & $\mathrm{C} / \mathrm{N}$ \\
\hline Tomatoes & $\mathrm{pH} 7.0+\mathrm{C} / \mathrm{N} 10$ & 7.0 & 10 \\
& $\mathrm{pH} 7.0+\mathrm{C} / \mathrm{N} 25$ & 7.0 & 25 \\
& $\mathrm{pH} 8.0+\mathrm{C} / \mathrm{N} 10$ & 8.0 & 10 \\
& $\mathrm{pH} 8.0+\mathrm{C} / \mathrm{N} 25$ & 8.0 & 25 \\
\hline Rice & $\mathrm{pH} 6.5+\mathrm{C} / \mathrm{N} 10$ & 6.5 & 10 \\
& $\mathrm{pH} 6.5+\mathrm{C} / \mathrm{N} 25$ & 6.5 & 25 \\
& $\mathrm{pH} 5.5+\mathrm{C} / \mathrm{N} 10$ & 5.5 & 10 \\
& $\mathrm{pH} 5.5+\mathrm{C} / \mathrm{N} 25$ & 5.5 & 25 \\
\hline
\end{tabular}


Table 3. Incorporation of ${ }^{18} \mathrm{~F}-\mathrm{FDG}$ in tomato and rice seedlings

\begin{tabular}{lll}
\hline Plants & Treatment & Mean (Value/pixel) \\
\hline Tomatoes & $\mathrm{pH} 7.0+\mathrm{C} / \mathrm{N} 10$ & 1171.92 \\
& $\mathrm{pH} 7.0+\mathrm{C} / \mathrm{N} 25$ & 731.70 \\
& $\mathrm{pH} 8.0+\mathrm{C} / \mathrm{N} 10$ & 4671.14 \\
& $\mathrm{pH} 8.0+\mathrm{C} / \mathrm{N} 25$ & 1430.73 \\
\hline Rice & $\mathrm{pH} 6.5+\mathrm{C} / \mathrm{N} 10$ & 5490.06 \\
& $\mathrm{pH} 6.5+\mathrm{C} / \mathrm{N} 25$ & 4292.78 \\
& $\mathrm{pH} 5.5+\mathrm{C} / \mathrm{N} 10$ & 5506.08 \\
& $\mathrm{pH} 5.5+\mathrm{C} / \mathrm{N} 25$ & 2153.52 \\
\hline
\end{tabular}
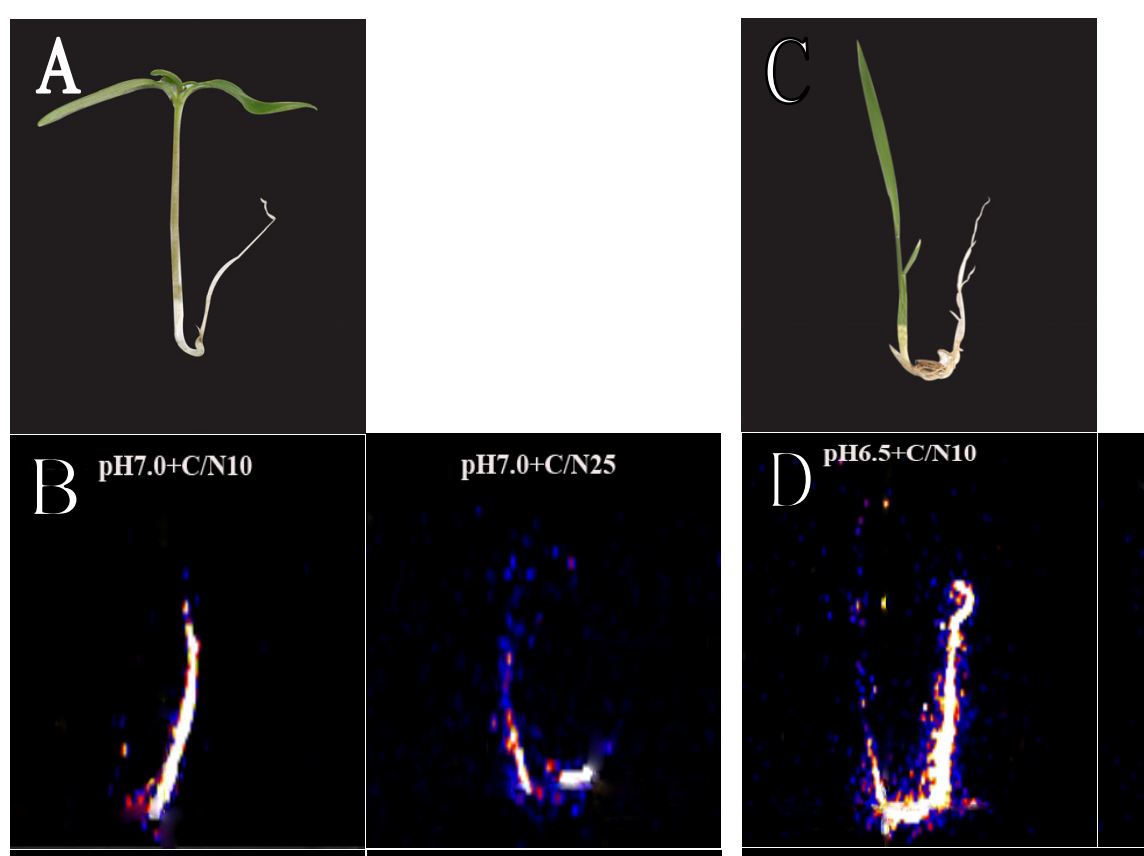

pH6.5+C/N25
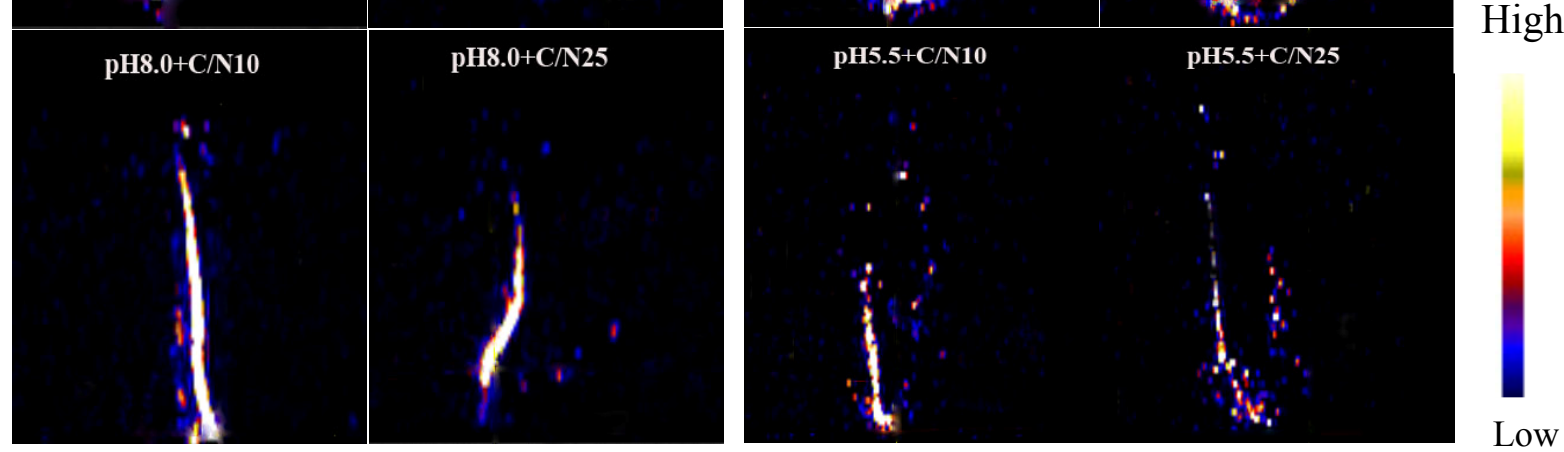

Figure 3. Translocation of ${ }^{18} \mathrm{~F}-\mathrm{FDG}$ in tomatoes and rice treated. (A) and (C) are representative gross images of the tomato and rice plant, respectively, which were measured using the PET system. The lower root half was immersed in the substrate solution containing ${ }^{18} \mathrm{~F}-\mathrm{FDG}$ under different $\mathrm{pH}$ and $\mathrm{C} / \mathrm{N}$ ratio conditions. PET images of tomatoes

(B) and rice (D) were obtained 5 hours later after ${ }^{18} \mathrm{~F}-\mathrm{FDG}$ was injected into the substrate solution

\subsection{Effects of $p H$ and $C / N$ Ratio}

Radioactivity present in roots, stems and leaves following the various $\mathrm{pH}$ and $\mathrm{C} / \mathrm{N}$ ratio treatments were measured by a detector after analyzing ${ }^{18} \mathrm{~F}-\mathrm{FDG}$ images obtained using PET. In tomato, the radioactivity of roots, stems and 
leaves decreased gradually from bottom to top; the results are displayed in decreasing order of transportation (Figure $4 \mathrm{~A}$ ): $\mathrm{pH} 8.0+\mathrm{C} / \mathrm{N} 10$ treatment $>\mathrm{pH} 7.0+\mathrm{C} / \mathrm{N} 10$ treatment $>\mathrm{pH} 8.0+\mathrm{C} / \mathrm{N} 25$ treatment $>\mathrm{pH} 7.0+\mathrm{C} / \mathrm{N} 25$ treatment. The root radioactivity at the $\mathrm{pH} 7.0+\mathrm{C} / \mathrm{N} 10$ and $\mathrm{pH} 8.0+\mathrm{C} / \mathrm{N} 10$ treatments was similar and significantly higher than at the $\mathrm{pH} 8.0+\mathrm{C} / \mathrm{N} 25$ and $\mathrm{pH} 7.0+\mathrm{C} / \mathrm{N} 25$ treatments. These results demonstrated that the lower $\mathrm{C} / \mathrm{N}$ ratio treatment promoted the absorption of the amino sugar by tomato roots. A significant difference between the stem and leaf radioactivity were also observed, which followed the same pattern of treatment preference.

The radioactivity of rice roots, stems and leaves also varied according to treatment conditions. Root radioactivity after the pH6.5+C/N10 treatment was greater than that after the other treatments. At $\mathrm{pH} 5.5$, only a slight difference in radioactivity was observed between a $\mathrm{C} / \mathrm{N}$ of 10 and of 25 , which suggests that the effect of the $\mathrm{C} / \mathrm{N}$ ratio on ASN absorption is diminished at low $\mathrm{pH}$ values. The stem radioactivity displayed the following decreasing order of transportation: $\mathrm{pH} 5.5+\mathrm{C} / \mathrm{N} 10$ treatment $>\mathrm{pH} 6.5+\mathrm{C} / \mathrm{N} 25$ treatment $>\mathrm{pH} 5.5+\mathrm{C} / \mathrm{N} 25$ treatment $>$ pH6.5 + C/N10 treatment (Figure 4B). The leaf radioactivity exhibited the following decreasing order of transportation: $\mathrm{pH} 5.5+\mathrm{C} / \mathrm{N} 10$ treatment $>\mathrm{pH} 6.5+\mathrm{C} / \mathrm{N} 10$ treatment $>\mathrm{pH} 6.5+\mathrm{C} / \mathrm{N} 25$ treatment $>\mathrm{pH} 5.5+\mathrm{C} / \mathrm{N} 25$ treatment. In conclusion, the $\mathrm{pH} 8.0+\mathrm{C} / \mathrm{N} 10$ and $\mathrm{pH} 5.5+\mathrm{C} / \mathrm{N} 10$ treatments yielded the greatest absorption and transportation outcomes for tomatoes and rice, respectively. The individual radioactive contributions from the root, stem and leaf were equivalent to the total plant radioactivity. These experiments validated the finding that of the treatments tested, $\mathrm{pH} 8.0+\mathrm{C} / \mathrm{N} 10$ and $\mathrm{pH} 5.5+\mathrm{C} / \mathrm{N} 10$ yielded the greatest absorption and transportation for tomatoes and rice, respectively. The tomato root radioactivity accounted for a range of $57.24 \%-89.64 \%$ of the total radioactivity, as displayed in the following descending order of activity (Figure $5 \mathrm{~A}$ ): $\mathrm{pH} 7.0+\mathrm{C} / \mathrm{N} 25$ treatment $>$ $\mathrm{pH} 7.0+\mathrm{C} / \mathrm{N} 10$ treatment $>\mathrm{pH} 8.0+\mathrm{C} / \mathrm{N} 25$ treatment $>\mathrm{pH} 8.0+\mathrm{C} / \mathrm{N} 10$ treatment. The stem and leaf contributions were $8.74 \%-38.20 \%$ and $1.62 \%-4.57 \%$, respectively. The highest stem and leaf radioactivity was observed after the $\mathrm{pH} 8.0+\mathrm{C} / \mathrm{N} 10$ treatment. These data demonstrated that ASN could be transported to the upper part of the tomatoes at an optimum $\mathrm{pH}$ of 8.0 and $\mathrm{C} / \mathrm{N}$ ratio of 10 . In rice, the root contributed up to $99.51 \%$ of the whole-plant radioactivity in the $\mathrm{pH} 6.5+\mathrm{C} / \mathrm{N} 10$ treatment; only a small amount of ${ }^{18} \mathrm{~F}-\mathrm{FDG}$ was transported to the stems and leaves. The maximum stem and leaf proportions were reached with the $\mathrm{pH} 5.5+\mathrm{C} / \mathrm{N} 10$ treatment, with values of $28.56 \%$ and $8.02 \%$, respectively (Figure $5 \mathrm{~B}$ ). These data revealed that ASN could be transported to the upper part of the rice plant at an optimum $\mathrm{pH}$ of 5.5 and $\mathrm{C} / \mathrm{N}$ ratio of 10 .

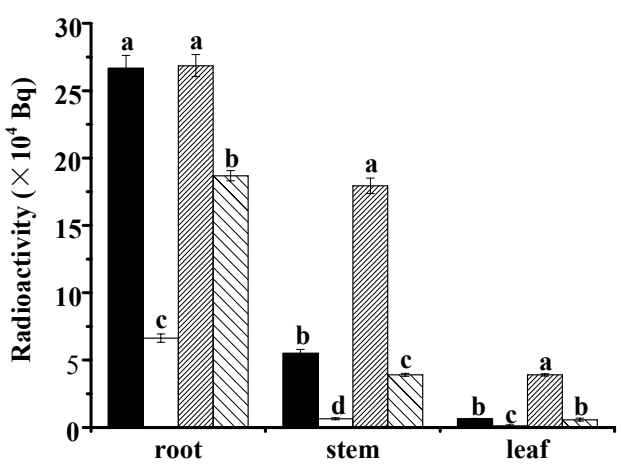

A

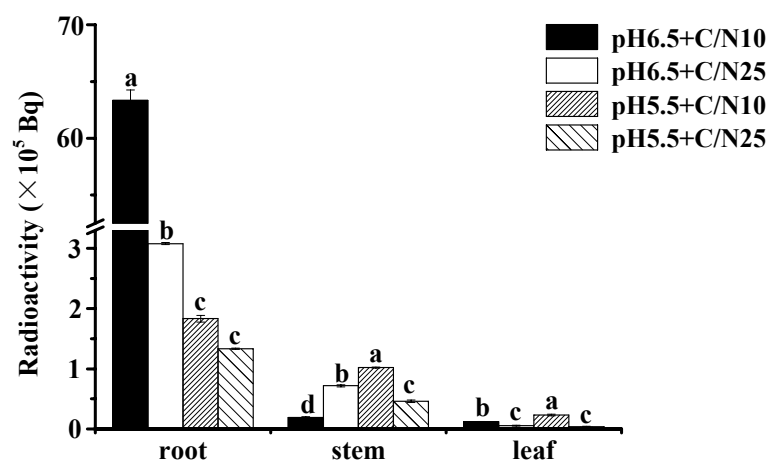

B

Figure 4. Measurement of radioactivity in roots, stems and leaves under different treatment conditions. Tomatoes (A) and rice (B) were cut into three parts (root, stem and leaf), and the radioactivity was determined for each part.

Error bars are the SD Statistically-significant differences between the different treatment conditions were determined using the Student's t-test; the different lower-case letters indicate significance difference at the $5 \%$ level 


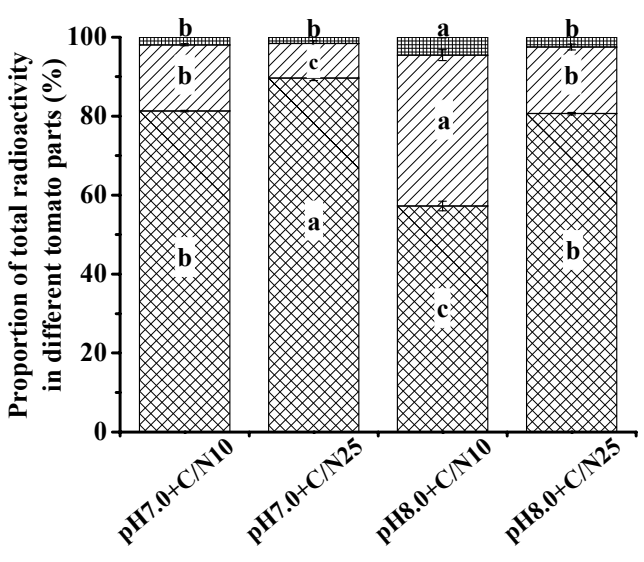

A

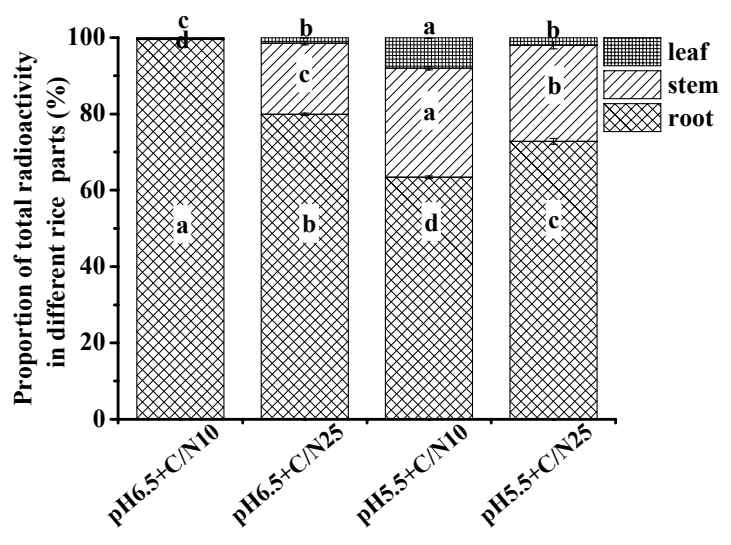

B

Figure 5. Measurement of the radioactivity proportions for the distinct plant parts under different treatment conditions for tomatoes (A) and rice (B). Error bars represent SD Statistically-significant differences between the different treatment conditions were determined using the Student's t-test; lower-case letters indicate significance at the $5 \%$ level

\section{Discussion}

The results of our study suggested that of the treatments tested, a $\mathrm{C} / \mathrm{N}$ of 10 was greatest for ASN absorption and translocation. Furthermore, tomatoes displayed better ASN absorption and transportation with slightly alkaline substrates, whereas rice had the greater ASN absorption and translocation in slightly acidic substrates. Previous research has demonstrated that ${ }^{18} \mathrm{~F}-\mathrm{FDG}$ and/or its metabolites could translocate via the phloem (Hattori et al., 2008), and the strength of the phloem transportation capacity was one of the key factors that influenced the ASN absorption and transportation.

Previous research has confirmed that neutral, acid and alkaline amino acid transporters existed at the root surface (Kinraide, 1981; Datko \& Mudd, 1985; Bush, 1993; Tanner \& Caspari, 1996; Fischer et al., 1998). The activities of these transporters were controlled by different environmental conditions, which were influenced by the $\mathrm{pH}$ as well as the sucrose and glucose content (Rentsch et al., 2007; Thornton, 2001). Some researchers have proposed that amino acid transporter expression was closely related to plant tissue and developmental stage (Liu \& Bush, 2006). Similarly, transporters were necessary for plants to absorb ASN, and its activity and gene expression might be influenced by the $\mathrm{pH}$ and $\mathrm{C} / \mathrm{N}$ ratio. To elucidate the mechanism of ASN absorption and transportation, it would be important to further explore physiological and biochemical plant indicators such as superoxide dismutase, peroxidase and MDA, the ultrastructure and protein structure of the roots, and the plant transcriptome, at the optimal $\mathrm{pH}$ and $\mathrm{C} / \mathrm{N}$ ranges.

\section{Conclusion}

In order to explore whether ASN can be absorbed directed by plants and what influenced the absorption. Positron Emission Tomography (PET) with ${ }^{18} \mathrm{~F}$-fluorodeoxyglucose $\left({ }^{18} \mathrm{~F}\right.$-FDG) was conducted in this study. We designed different $\mathrm{C} / \mathrm{N}$ level (10 and 25) and $\mathrm{pH}$ level (5.5 and 6.5 in rice and 7.0 and 8.0 in tomato). The results suggested that ASN was absorbed directly by tomatoes and rice and this absorption was significantly influenced by the carbon to nitrogen ratio $(\mathrm{C} / \mathrm{N})$ and the $\mathrm{pH}$ value of the growth substrate solution of tomatoes and rice. A $\mathrm{C} / \mathrm{N}$ of 10 was greatest for ASN absorption and translocation. Furthermore, tomatoes displayed better ASN absorption and transportation with slightly alkaline substrates, whereas rice had the greater ASN absorption and translocation in slightly acidic substrates.

\section{Acknowledgements}

We would like to thank the National Basic Research Program (973 program) of China (2013CB127406), the National Natural Science Foundation of China (21107139), the Special Fund of Research Institute Technology Development (2012EG134235), the Ministry of Agriculture Public Benefit Research Foundation of China (201103007) and the Transformational Fund of Agricultural Scientific and Technological Achievements (2012GB23260542) for their financial support. We also thank Professor Zhang Jin-Ming for contributing the

${ }^{18}$ F-FDG research data, the Explore Vista Micro PET imaging system data and for their expert guidance and 
intellectual contributions.

\section{Reference}

Sigel, A., \& Sigel, H. (1998). Iron transport and storage in microorganisms, plants and animals. Met Based Drugs, 35, 215-237. http://dx.doi.org/10.1155/MBD.1998.262a

Bremner, J. M. (1965). Organic forms of nitrogen (C. A. Black Ed.). Methods of Soil Analysis. American Society of Agronomy, 9, 1148-1178.

Bremner, J. M. (1967). Soil Biochemistry. New York: Marcel Dekker.

Bush, D. R. (1993). Proton-coupled sugar and amino acid transporters in plants. Annu.Rev. Plant. Physiol Plant. Mol. Biol., 44, 513-542. http://dx.doi.org/10.1146/annurev.arplant.44.1.513

Datko, A. H.. \& Mudd, S. H. (1985). Uptake of amino acids and other organic compounds by Lemna paucicostata Hegelm. Plant Physiol., 77, 770-778. http://dx.doi.org/10.1104/pp.77.3.770

Lee, E., Kamlet, A. S., Powers, D. C., Neumann, C. N., Boursalian, G. B., Furuya, T., ... Ritter, T. (2011). A fluoride-derived electrophilic late-stage fluorination reagent for PET imaging. Science, 334, 639-642. http://dx.doi.org/10.1126/science.1212625

Falkengren, G. U., Mansson, K. F., \& Olsson, M. O. (2000). Uptake capacity of amino acids by ten grasses and forbs in relation to soil acidity and nitrogen availability. Environ Exp Bot., 44(3), 207-219. http://dx.doi.org/10.1016/S0098-8472(00)00068-X

Ferrieri, A. P., Appel, H., Ferrieri, R. A., \& Schultz, J. C. (2012). Novel application of 2- $\left[{ }^{18} \mathrm{~F}\right]$ fluoro-2-deoxyD-glucose to study plant defenses. Nucl Med and Biol., 39, 1152-1160. http://dx.doi.org/10.1016/j.nucmedbio.2012.06.005

Fischer, W. N., Andre, B., Rentsch, D., Krolkiewicz, S., Tegeder, M., Breitkeuz, K., \& Frommer, W. (1998). Amino acid transport in plant. Trends in Plant Science, 3, 188-195. http://dx.doi.org/10.1016/S1360-1385(98)01231-X

Hattori, E., Uchida, H., Harada, N., Ohta, M., Tsukada, H., Hara, Yasuhiro., \& Suzuki, T. (2008). Incorporation and translocation of 2-deoxy-2- $\left[{ }^{18} \mathrm{~F}\right]$ fluoro-D-glucose in Sorghum bicolor (L.) Moench monitored using a planar positron imaging system. Planta, 227, 1181-1186. http://dx.doi.org/10.1007/s00425-008-0701-9

Kinraide, T. B. (1981). Inter amino acid inhibition of transport in higher plants.evidence for 2 transport channels with ascertainable affinities for amino acids. Plant Physiol., 68, 1327-1333.

Kiyomiya, S., Nakanishi, H., Uchida, H., Tsuji, A., Nishiyama, S., Futatsubashi, M., ... Moriginal, S. (2001). Real time visualization if ${ }^{13} \mathrm{~N}$-translocation in rice under different environmental conditions using positron emitting tracer imaging system. Plant Physiol., 125, 1743-1753.

Lee, E., Kamlet, A. S., Powers, D. C., Neumann, C. N., Boursalian, G. B., Furuya, T., ... Ritter, T. (2011). A fluoride-derived electrophilic late-stage fluorination reagent for PET imaging. Science, 334, 639-642. http://dx.doi.org/10.1126/science.1212625

Liu, Y. M., \& Liu, X. H. (2010). Comparison of methods for determining the content of hydrolyzed amino sugar-N and amino acid-N in soil. J. Jilin Agricultural Sciences., 22, 19-23 (in Chinese with English abstract).

Liu, X., \& Bush, D. R. (2006). Expression and transcriptional regulation of amino acid transporters in plants. Amino Acids, 30, 113-120. http://dx.doi.org/10.1007/s00726-005-0248-z

Nakanishi, H., Bughio, N., Matsuhashi, S., Ishioka, N. S., Uchida, H., Tsuji, A., ... Mori, S. (1999). Visualizing real time $\left[{ }^{11} \mathrm{C}\right]$ methionine translocation in Fe-sufficient and Fe-deficient barley using a positron emitting tracer imaging system (PETIS). J.Exp Bot., 50, 637-643. http://dx.doi.org/10.1093/jexbot/50.334.637

Nakanishi, T. M., Tanoi, K., Yokota, H., Kang, D. J., Ishii, R., Ishioka, N. S., ... Tsuji, A. (2001). ${ }^{18}$ F used as tracer to study water uptake and transport imaging of a cowpea plant. J. Radioanal. Nucl. Chem., 249, 503-507.

Ohtake, N. Sato, T. Fujikake, H., Sueyoshi, K., Ohyama, T., Ishioka, N. S., ... Tsuji, A. (2001). Rapid N transport to pods and seeds in N-deficient soybean plants. J. Exp. Bot., 52, 277-283. http://dx.doi.org/10.1093/jexbot/52.355.277

Persson, J., \& Näsholm, T. (2003). Regulation of amino acid uptake by carbon and nitrogen in Pinus sylvestris. Planta, 217, 309-315. 
Reeve, J. R., Smith, J. L., Lynne, C. B., \& Reganold, J. P. (2008). Soil-based cycling and differential uptake of amino acids by three species of strawberry (Fragaria spp.) plants. Soil Biology \& Biochemistry., 40, 2547-2252. http://dx.doi.org/10.1016/j.soilbio.2008.06.015

Rentsch, D., Schmidt, S., \& Tegeder, M. (2007). Transporters for uptake and allocation of organic nitrogen compounds in plants. FEBS Letters, 581, 2281-2289. http://dx.doi.org/10.1016/j.febslet.2007.04.013

Schobert, C., \& Komor, E. (1987). Amino acid uptake by Ricinus communis roots: characterization and physiological significance. Plant, Cell \& Environment, 10(6), 493-500. http://dx.doi.org/10.1111/j.1365-3040.1987.tb01827.x

Schiller, P., Heilmeier, H., \& Hartung, W. (1998). Uptake of amino acids by the aquatic resurrections plant Chamaegigas intrepidus and its implications for $\mathrm{N}$ nutrition. Oecologia, 63, 117. http://dx.doi.org/10.1007/s004420050632

Stevenson, F. J. (1982). Nitrogen in Agricultural Soil. American Society of Agronomy, 605-649.

Tanner, W., \& Caspari, T. (1996). Membrane transport carriers. Annu.Rev. Plant. Physiol Plant. Mol. Biol., 47, 595-626. http://dx.doi.org/10.1146/annurev.arplant.47.1.595

Thornton, B. (2001). Uptake of glycine by non-mycorrhizal Loliunm perenne. J. Exp Bot., 52, 1315-1322. $\mathrm{http}: / / \mathrm{dx}$. doi.org/10.1093/jexbot/52.359.1315

Weissleder, R. (2006). Molecular imaging in cancer. Science, 312, 1168-1171. http://dx.doi.org/10.1126/science.1125949

Yang, D., Yukihiro, M., Yu, D. F., Ito, M., Oh, C. S., Kohanim, S., ... Podoloff, D. (2004). Assessment of therapeutic tumor response using ${ }^{99} \mathrm{~m}$ Tc-Ethyleenedicysteine-Glucosamine. Cancer Biotherapy \& Radiopharmaceuticals, 19(4), 443-456. http://dx.doi.org/10.1089/1084978041979625

Yang, D. J., Kim, C. G., Schechter, N. R., Azhdarinia, A., Yu, D. F., Oh, C. S., ... \& Podoloff, D. A. (2003). Imaging with $99 \mathrm{mTc}$ ECDG targeted at the multifunctional glucose transport system: feasibility study with Rodents1. Radiology, 226(2), 465-473. http://dx.doi.org/10.1148/radiol.2262011811

Zhang, F. D., \& Sun, X. (1984). A study of nutrition of amino acids in rice seedlings. Scientia Agricultura Sinica, 64,5 .

\section{Copyrights}

Copyright for this article is retained by the author(s), with first publication rights granted to the journal.

This is an open-access article distributed under the terms and conditions of the Creative Commons Attribution license (http://creativecommons.org/licenses/by/3.0/). 